\title{
Ornithine decarboxylase as a monitor for luteal stimuli in the pregnant rat
}

\author{
D. Hickman-Smith, L. E. Bussmann* and N. J. Kuhn \\ Department of Biochemistry, University of Birmingham, Birmingham B15 2TT, U.K.
}

\begin{abstract}
Summary. The sustained elevation during Days 12-21 of pregnancy of rat luteal ornithine decarboxylase, which is inducible experimentally by hCG and PGF-2 $\alpha$, was dependent upon intact placentae and oestrogen, but independent of prostaglandin, and was absent at corresponding times of pseudopregnancy. It is suggested that this enzyme activity is a response to an hCG-like hormone of placental origin. Two brief reappearances of enzyme activity on Days 21 and 22 of pregnancy, dependent upon intact placentae and upon both oestrogen and prostaglandin, suggest a pulsatile release of PGF-2 $\alpha$ from the uterus or placentae. These experiments illustrate the value of ornithine decarboxylase in seeking unknown hormonal influences upon the corpus luteum.
\end{abstract}

\section{Introduction}

The hormonal control of luteal function is poorly understood, especially during late pregnancy. In the rat, dependence upon luteinizing hormone (LH) is replaced at about Day 12-15 by dependence upon the placenta (Moudgal, Behrman \& Greep, 1972; Mukku \& Moudgal, 1976). The abrupt withdrawal of progesterone during the last $48 \mathrm{~h}$ of pregnancy in rats can largely be ascribed to the induction of luteal $20 \alpha$-hydroxysteroid dehydrogenase, which metabolizes progesterone to $20 \alpha$-dihydroprogesterone. Identification of the hormonal signal for this induction is therefore important to understand the termination of pregnancy and the initiation of lactation, which are associated with progesterone withdrawal (Wiest, Kidwell \& Balogh, 1968; Kuhn \& Briley, 1970; Bussmann \& Deis, 1979).

Despite the several ways in which $20 \alpha$-hydroxysteroid dehydrogenase can be induced experimentally in the late-pregnant rat, the natural signal has not been clearly established. Induction by placental removal is partly reversed by LH, hCG or PMSG, suggesting that a chorionic gonadotrophin of similar properties might suppress the induction of the enzyme until its withdrawal at the end of pregnancy (Hickman-Smith \& Kuhn, 1976). Several reports have indicated the existence of such a hormone in rat placenta, but its nature remains uncertain (Bambra \& Gombe, 1978; Blank, Dufau \& Friesen, 1979). Oestrogen appears also to restrain induction of the enzyme after Day 18 (Hickman-Smith \& Kuhn, 1976). Alternatively these influences might be overridden at the end of pregnancy by a luteolytic hormone such as prostaglandin F-2 $\alpha$. This hormone effectively induces $20 \alpha$-hydroxysteroid dehydrogenase when it is injected, especially when nearer the time of parturition (Strauss \& Stambaugh, 1974; Fuchs \& Mok, 1974; Rodway \& Kuhn, 1975; Bussmann \& Deis, 1979). Moreover indomethacin, an inhibitor of prostaglandin synthesis, blocks the natural induction of the enzyme (Strauss \&

\footnotetext{
* Present address: Laboratorio de Reproducción y Lactancia, C.O.N.I.C.E.T. Casilla de Correo 855, 5500 Mendoza, Argentina.
} 
Stambaugh, 1974). Although this type of experiment cannot locate the source or the site of action of prostaglandin, the hormone does arise from the uterus, and possibly from the placenta, in greater quantities as parturition approaches (Labhsetwar \& Watson, 1974; Harney, Sneddon $\&$ Williams, 1974). None of these hormones has yet been linked with the influence of the time of day upon the induction of luteal 20a-hydroxysteroid dehydrogenase (Lincoln \& Porter, 1979; Hickman-Smith \& Kuhn, 1980).

In view of these uncertainties we have employed luteal ornithine decarboxylase to monitor suspected or unknown hormonal influences upon the corpus luteum of pregnancy. This enzyme occurs in a variety of vertebrate tissues, being induced in each by one of a small number of hormonal stimuli peculiar to that tissue (Tabor \& Tabor, 1976). In the ovary of the non-pregnant rat it is induced by $\mathbf{L H}$ and prostaglandin, but little or not at all by FSH, TSH, insulin, oestradiol-17 $\beta$, progesterone, testosterone or thyroxine (Kobayashi, Kupelian \& Maudsley, 1971; Lamprecht, Zor, Tsafriri \& Lindner, 1973; Nureddin, 1977; D. Hickman-Smith \& N. J. Kuhn, unpublished results). Since its unusually short half-life of 10-20 min ensures that any induction is rapid and transient, it is likely that the enzyme activity faithfully follows changing concentrations of suitable stimuli, as for example, during the oestrous cycle (Kobayashi et al., 1971).

\section{Materials and Methods}

\section{Animals and treatments}

Time-mated, primigravid Wistar-derived rats were used as described by Hickman-Smith \& Kuhn (1980). About $80 \%$ of the mothers in the colony littered between 17:30 h on Day 22 and 17:30 h on Day 23, and about $65 \%$ between $09: 00 \mathrm{~h}$ and 17:30 h on Day 23 . The mean length of pregnancy has slightly lengthened during the past 2 years and the distribution of birth times does not appear to resemble that recorded by Lincoln \& Porter (1976). Food and water were available ad libitum, and artificial lighting extended from 06:00 to 20:00 h British Summer Time. Prostaglandins and aminoglutethimide were administered s.c. in $0.25 \mathrm{ml} 0.9 \%(\mathrm{w} / \mathrm{v}) \mathrm{NaCl}$. Cycloheximide and hCG were given i.p. in $0.5 \mathrm{ml} 0.9 \%(\mathrm{w} / \mathrm{v}) \mathrm{NaCl}$. Oestradiol-17 $\beta$ was given s.c. in $0.25 \mathrm{ml}$ arachis oil, and indomethacin s.c. in $0.25 \mathrm{ml} 0.1 \mathrm{M}$-potassium phosphate buffer, $\mathrm{pH} \mathrm{7.2.} \mathrm{The} \mathrm{surgical} \mathrm{removal} \mathrm{of} \mathrm{fetuses,} \mathrm{with} \mathrm{or} \mathrm{without} \mathrm{placenta,} \mathrm{was} \mathrm{carried} \mathrm{out} \mathrm{through} \mathrm{a}$ ventral incision under light ether anaesthesia.

Daily vaginal smears were taken to establish the timing of the oestrous cycle in each rat, and were continued throughout pseudopregnancy. Rats were made pseudopregnant by $45 \mathrm{sec}$ cervical stimulation with a glass rod on the afternoon of the day on which a positive oestrous smear was obtained (Day 0). The first appearance of leucocytes denoted Day 1 of pseudopregnancy. These animals either received no further treatment, or else underwent traumatization of both uterine horns on the afternoon of Day 4 by means of a needle scratch extending the full length of the endometrium. This was carried out through a lateral abdominal incision.

Rats were killed by decapitation. Pairs of trimmed ovaries $(60-140 \mathrm{mg})$ were homogenized in a glass tube fitted with a motor-driven Teflon pestle in $2.0 \mathrm{ml}$ cold 50 mM-sodium phosphate buffer, $\mathrm{pH} 7 \cdot 2$, containing $5 \mathrm{~mm}$-dithiothreitol and $10 \mathrm{mM}$-EDTA, and the homogenate was centrifuged at $5^{\circ} \mathrm{C}$ for $30 \mathrm{~min}$ at $10000 \mathrm{~g}$. The resulting clear supernatant fluid was assayed for ornithine decarboxylase activity by Nureddin's (1977) modification of the method of Russell \& Snyder (1968), except that the pyridoxal phosphate concentration was 2 $\mu \mathrm{M}$ and that phenylethylamine-methanol $(1: 1 \mathrm{v} / \mathrm{v})$ replaced hyamine hydroxide. Filter papers containing ${ }^{14} \mathrm{CO}_{2}$ were transferred to $5 \mathrm{ml}$ scintillation fluid and counted for $10 \mathrm{~min}$ on a channels ratio programme in a Philips model PW4510/01 liquid scintillation analyser. Supernatant fluids were stored up to $72 \mathrm{~h}$ at $-17^{\circ} \mathrm{C}$ before assay without loss of activity. $20 \alpha$-Hydroxysteroid dehydrogenase in the same extracts was assayed as previously described (Hickman-Smith \& Kuhn, 1980). 
Rats serving as controls for drug- or hormone-treated animals were injected with vehicle alone under otherwise identical conditions and at the same time. Removal of the fetuses served as a control for removal of the conceptus, although some animals were later discarded when it was obvious that the remaining placentae had become detached. The significance of differences between groups was assessed by Student's $t$ test.

\section{Materials}

Time-mated, Wistar-derived rats, hypophysectomized on Day 13 of pregnancy, were purchased from Charles River U.K., Ltd, Margate, Kent, U.K., and were transported on Day 15. Crude hCG (Pregnyl) was from Organon, Morden, Surrey, U.K. Prostaglandin F-2 $\alpha$ tromethamine salt (Lutalyse) and prostaglandin E-2 (Prostin $\mathrm{E}_{2}$ ) were kindly given by Mrs C. A. Russell, Upjohn Ltd, Crawley, West Sussex, U.K. Aminoglutethimide (Elipten) was a gift from Dr R. M. Burley, CIBA-GEIGY Research Laboratories, Horsham, Surrey, U.K., and indomethacin was donated by Merck, Sharp and Dohme Research Laboratories, Rahway, New Jersey, U.S.A. Cycloheximide (actidione) was from Koch-Light Laboratories, Colnbrook, Bucks, U.K. Oestradiol-17 $\beta$, dithiothreitol and $\beta$-phenylethylamine were from Sigma (London) Chemical Co., Ltd, London SW6, U.K. L- $\left[1-{ }^{14} \mathrm{C}\right]$ ornithine monohydrochloride was from the Radiochemical Centre, Amersham, Bucks, U.K., and L-ornithine monohydrochloride was from BDH Chemicals Ltd, Poole, Dorset, U.K.

Subaseal caps and polyethylene centre wells were purchased from Uniscience Ltd, Cambridge, U.K. Scintillation fluid was prepared by dissolving $4 \mathrm{~g} \mathrm{2:5-diphenyloxazole} \mathrm{and} 120$ mg 1:4-di-2-(5-phenyloxazolyl)-benzene in 1 litre toluene.

\section{Results}

Activity of ornithine decarboxylase during pregnancy and pseudopregnancy

As shown in Text-fig. 1, activity in pregnancy appeared on about Day 12 and rose to a peak at Day 15. Relatively high levels were then maintained until Day 20, after which activity declined to nearly zero at parturition. These changes are similar to those reported by Sheth \& Moodbidri (1977), although there are differences of detail in the timing. By contrast, there was no rise of

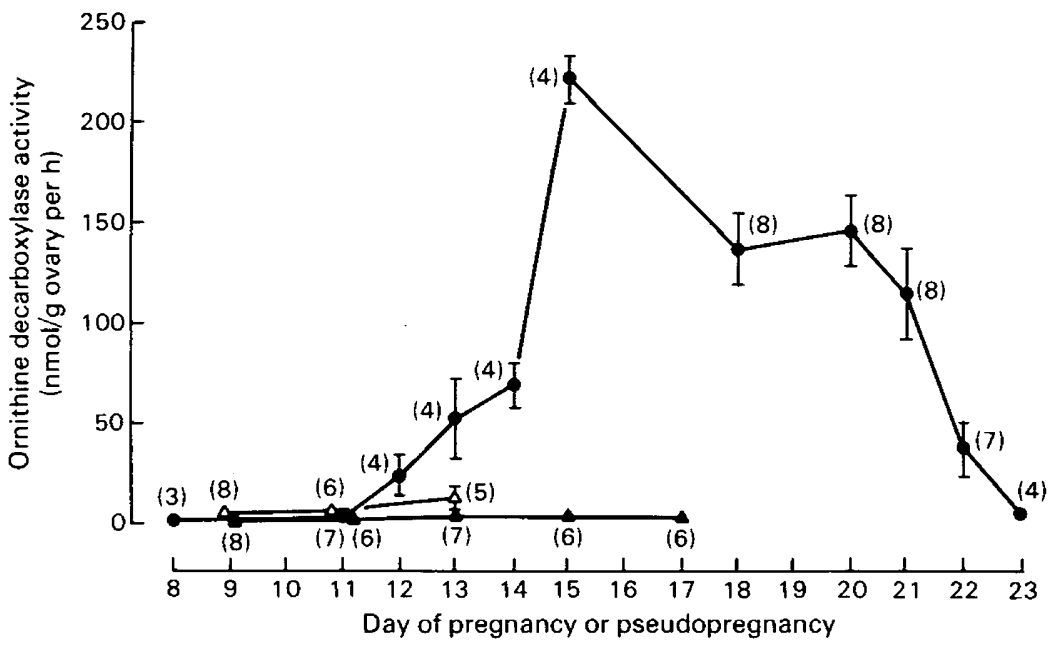

Text-fig. 1. Ovarian ornithine decarboxylase activity during pregnancy (O) and during pseudopregnancy with $(\Delta)$ and without $(\Delta)$ decidual tissue. Rats were killed between 10:00 and 12:00 $\mathrm{h}$ on the days indicated. Values are mean \pm s.e.m. for the no. of rats given in parentheses. 
activity at all in the corpora lutea of pseudopregnant rats, whether or not they carried decidual tissue.

A detailed, 2-hourly mapping of the activity during Days 20 to 22 revealed two brief peaks of activity at 21:00-23:00 h on Day 21 and at 13:00-15:00 h on Day 22 (Text-fig. 2). No such peak(s) occurred on Day 20, although on that day the mean activity of ornithine decarboxylase during daylight hours did significantly $(P<0.001)$ exceed the mean activity in the subsequent dark period. Examination of animals at various stages of pregnancy, and also after treatment with prostaglandin F-2 $\alpha$ on Day 18 (see below), showed that about $90 \%$ of the ovarian ornithine decarboxylase activity was confined to the readily dissectable corpora lutea.

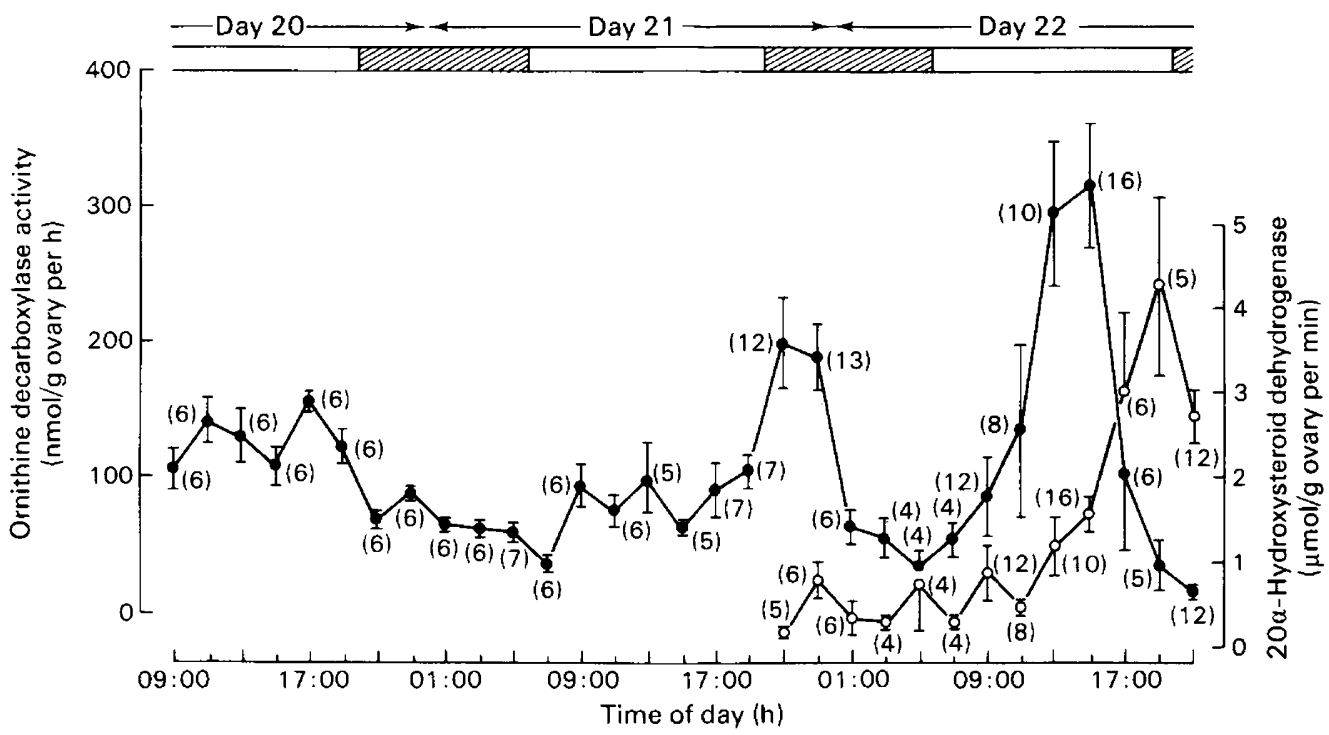

Text-fig. 2. Variation in activity of ornithine decarboxylase (0) and of $20 \alpha$-hydroxysteroid dehydrogenase $(O)$ in late pregnancy. Hatched bars show the periods of darkness. Values are mean \pm s.e.m. for the no. of rats given in parentheses.

The rising luteal activity of $20 a$-hydroxysteroid dehydrogenase in the same pregnant rats is also shown by way of reference (Text-fig. 2), since the exact timing of such pre-partum events is otherwise difficult to establish and to compare with work from other laboratories. The activity of $20 \alpha$-hydroxysteroid dehydrogenase also tended to rise at the end of pseudopregnancy (data not shown). Mammary lactose was present in some of the rats sampled after 15:00 h on Day 22 (data not shown), thus placing them within about $12 \mathrm{~h}$ of parturition (Kuhn, 1969).

\section{Activity of ornithine decarboxylase in experimentally treated rats}

Table 1 shows the results of experiments carried out at, or around, Day 18 of pregnancy to study the prolonged elevation of activity up to Day 20 . Ornithine decarboxylase activity was unaffected by removal of the fetuses, but was greatly lowered by removal of the entire conceptus. The administration of hCG to such animals returned the activity part-way $(P<0.0001)$ towards normal. By contrast, hypophysectomy did not lower the activity, but appeared rather to raise it. These findings suggest that the ornithine decarboxylase activity during this period of pregnancy might be due to the influence of a placental gonadotrophin that first appears around Day 12. Consistent with this, the enzyme could be induced prematurely 
by hCG on Days 8 and 11 , mean \pm s.e.m. values being $72 \pm 17(\mathrm{~N}=3)$ and $106 \pm 4(\mathrm{~N}=5)$ $\mathrm{nmol} / \mathrm{g}$ ovary per $\mathrm{h}$ respectively. However, the injection of hCG to intact pregnant rats on Day 17 or 18 lowered the existing enzyme activity at 5 and at $24 \mathrm{~h}$, possibly due to a down-regulation of hormone receptors (Conti, Harwood, Dufau \& Catt, 1977).

Table 1. Activity of ovarian ornithine decarboxylase around Day 18 of pregnancy in variously treated rats

\begin{tabular}{|c|c|c|c|c|}
\hline \multirow[b]{2}{*}{ Treatment } & \multirow[b]{2}{*}{$\begin{array}{l}\text { Time of treatment } \\
\text { (h before death) }\end{array}$} & \multirow[b]{2}{*}{$\begin{array}{c}\text { Day } \\
\text { killed }\end{array}$} & \multicolumn{2}{|c|}{$\begin{array}{l}\text { Activity of ornithine decarboxylase } \\
\text { (nmol/g ovary per } \mathrm{h})\end{array}$} \\
\hline & & & Experimental & $\begin{array}{l}\text { Unoperated or } \\
\text { vehicle-injected } \\
\text { controls }\end{array}$ \\
\hline Fetus removal & 24 & 18 & $124 \pm 19(5)$ & \\
\hline Conceptus removal & 24 & 18 & $* * * 24 \pm 6(7)$ & $114 \pm 8(6)$ \\
\hline $\begin{array}{l}\text { Conceptus removal + hCG } \\
\text { (150 or } 300 \text { i.u. })\end{array}$ & $24+5$ & 18 & $* * * 76 \pm 7(8)$ & \\
\hline Hypophysectomy & 72 & 16 & $* * 88 \pm 4(6)$ & $40 \pm 11(6)$ \\
\hline Hypophysectomy & 168 & 20 & $69 \pm 19(6)$ & $46 \pm 7(6)$ \\
\hline hCG (300 i.u.) i.p. & 5 & 18 & $* * 59 \pm 11(5)$ & $100+0(15)$ \\
\hline hCG (300 i.u.) i.p. & 24 & 18 & $* 71 \pm 6(5)$ & $109 \pm 9(10)$ \\
\hline Indomethacin $(1 \times 2 \mathrm{mg})$ & 24 & 18 & $134 \pm 18(6)$ & $148+21(7)$ \\
\hline Indomethacin $(2 \times 1 \mathrm{mg})$ & $24+12$ & 18 & $185 \pm 27(6)$ & $148 \pm 21(7)$ \\
\hline Indomethacin $(1 \times 1 \mathrm{mg})$ & 5 & 18 & $168 \pm 11(5)$ & $142 \pm 23(4)$ \\
\hline PGF- $2 \alpha(2 \times 100 \mu \mathrm{g})$ & $24+21$ & 18 & $* * * 230 \pm 33(6)$ & $109 \pm 9(15)$ \\
\hline PGF-2 $\alpha(1 \mu \mathrm{g})$ & 5 & 18 & $* * 305 \pm 23(5)$ & $168 \pm 25(12)$ \\
\hline PGE-2 $(5 \mu \mathrm{g})$ & 5 & 18 & $172 \pm 22(5)$ & \\
\hline PGE-2 $(12.5 \mu \mathrm{g})$ & 5 & 18 & $231 \pm 29(5)$ & $141 \pm 31(6)$ \\
\hline PGE-2 $(25 \mu \mathrm{g})$ & 5 & 18 & $182 \pm 30(5)$ & \\
\hline Aminoglutethimide $(25 \mathrm{mg}$ ) & 5 & 18 & $* * * 19 \pm 4(9)$ & \\
\hline PGF-2a $(50 \mu \mathrm{g})$ & 5 & 18 & ${ }^{* * *} 642 \pm 83(5)$ & $172 \pm 17(8)$ \\
\hline $\begin{array}{l}\text { Aminoglutethimide }(25 \mathrm{mg})+ \\
\text { PGF- } 2 \alpha(50 \mu \mathrm{g})\end{array}$ & 5 & 18 & $* * 289 \pm 83(5)$ & \\
\hline Aminoglutethimide ( $25 \mathrm{mg}$ ) & 5 & 18 & $* * 17 \pm 4(5)$ & \\
\hline Oestradiol- $17 \beta(50 \mu \mathrm{g})$ & 5 & 18 & $204 \pm 32(5)$ & $142 \pm 30(6)$ \\
\hline $\begin{array}{l}\text { Aminoglutethimide }(25 \mathrm{mg})+ \\
\text { oestradiol-17ß }(50 \mu \mathrm{g})\end{array}$ & 5 & 18 & $169 \pm 23(6)$ & \\
\hline
\end{tabular}

Values are mean \pm s.e.m. with the no. of rats in parentheses.

Compared with control value, ${ }^{*} P<0.05 ;^{* *} P<0.01$; ${ }^{* * *} P<0.001$ (Student's $t$ test).

Prostaglandin synthesis was apparently not required to maintain the ornithine decarboxylase activity at this stage, since the administration of indomethacin caused no change (Table 1). Nevertheless extra activity was invoked by injected PGF-2 $\alpha$, although not by PGE-2. Table 2 shows that ornithine decarboxylase was maximally induced at doses of 25-50 $\mu \mathrm{g}$ PGF-2 $\alpha$. Comparison of Tables 1 and 2 suggests that the response over $24 \mathrm{~h}$ is less than over $5 \mathrm{~h}$, consistent with the experience of most workers that ornithine decarboxylase is maximally induced about $5 \mathrm{~h}$ after stimulus.

In a further series of experiments on 18-day-pregnant rats (Table 1) both the normal and the PG-induced activities of ornithine decarboxylase were much reduced by aminoglutethimide. The effect of this compound, which is known to inhibit steroid biosynthesis, was fully reversed by simultaneous administration of oestradiol-17 $\beta$. These findings suggest that oestrogen is required for the induction of the enzyme within the corpus luteum; they do not indicate whether or not oestrogen is required for the placental stimulus.

Table 3 shows the results of similar experiments carried out to examine the hormone 
Table 2. Induction of ovarian ornithine decarboxylase on Day 18 of pregnancy by different doses of PGF- $2 \alpha$ injected $5 \mathrm{~h}$ before death at about $15: 00 \mathrm{~h}$

\begin{tabular}{|c|c|c|}
\hline PGF- $2 \alpha(\mu \mathrm{g})$ & $\begin{array}{l}\text { Activity of ornithine decarboxylase } \\
\text { (nmol/g ovary per } \mathrm{h} \text { ) }\end{array}$ & Significance* \\
\hline 0 & $168 \pm 25(12)$ & - \\
\hline 1 & $305 \pm 23(5)$ & $P<0.01$ \\
\hline 5 & $467 \pm 53(5) \dagger$ & $P<0.05$ \\
\hline $12 \cdot 5$ & $426 \pm 33(5)$ & N.S. \\
\hline 25 & $753 \pm 53(3))$ & \\
\hline 50 & $762 \pm 49(2)\} 730 \pm 30(8)$ & $P<0.001$ \\
\hline 100 & $687 \pm 58(3))$ & \\
\hline
\end{tabular}

Values are mean \pm s.e.m. for the no. of rats in parentheses.

- Compared to value for the next lowest dose of PGF-2 $\alpha$.

$\uparrow$ This value is significantly different from the combined value for the highest 3 doses, $P<0.001$.

Table 3. Effect of various treatments on ovarian ornithine decarboxylase at different times on Days 21 and 22 of pregnancy

\begin{tabular}{|c|c|c|c|c|}
\hline \multirow[b]{3}{*}{ Treatment $\dagger$} & \multirow{2}{*}{\multicolumn{2}{|c|}{ Death }} & \multicolumn{2}{|c|}{$\begin{array}{l}\text { Activity of ornithine decarboxylase } \\
\text { (nmol/g ovary per } \mathrm{h} \text { ) }\end{array}$} \\
\hline & & & \multirow[b]{2}{*}{ Experimental } & \multirow{2}{*}{$\begin{array}{l}\text { Unoperated or } \\
\text { vehicle-injected } \\
\text { controls }\end{array}$} \\
\hline & Day & Time (h) & & \\
\hline Aminoglutethimide $(25 \mathrm{mg})$ & 21 & $21: 00$ & $* 61 \pm 31(6)$ & $191 \pm 39(5)$ \\
\hline Aminoglutethimide $(25 \mathrm{mg})$ & 22 & $15: 00$ & $80 \pm 40(5)$ & $305 \pm 65(5)$ \\
\hline Indomethacin (1 mg) & 21 & $21: 00$ & $* * * 88 \pm 15(7)$ & $261 \pm 34(6)$ \\
\hline Indomethacin (1 mg) & 22 & $15: 00$ & $* * 113 \pm 33(5)$ & $448 \pm 77(3)$ \\
\hline PGF- $2 \alpha(50 \mu \mathrm{g})$ & 22 & $15: 00$ & $415 \pm 74(6)$ & $285 \pm 70(5)$ \\
\hline PGE-2 $(100 \mu \mathrm{g})$ & 22 & $15: 00$ & $197 \pm 66(4)$ & $255 \pm 117(3)$ \\
\hline Oestradiol-17ß $(50 \mu \mathrm{g})$ & 22 & $15: 00$ & $286 \pm 56(8)$ & $390 \pm 32(9)$ \\
\hline Oestradiol-17 $\beta(50 \mu \mathrm{g})$ & 21 & $17: 00$ & $123 \pm 12(5)$ & $64 \pm 10(3)$ \\
\hline Oestradiol-17 $\beta(50 \mu \mathrm{g})$ & 22 & $10: 00$ & $* * 381 \pm 61(5)$ & $107 \pm 38(5)$ \\
\hline Oestradiol-17 $\beta(50 \mu \mathrm{g})$ & 22 & $21: 00$ & $54 \pm 29$ & $21 \pm 11(4)$ \\
\hline PGF-2 $\alpha(50 \mu \mathrm{g})$ & 22 & 09:00 & $* 162 \pm 48(6)$ & $19 \pm 7(6)$ \\
\hline PGF- $2 \alpha(50 \mu \mathrm{g})$ & 22 & $21: 00$ & $65 \pm 20(4)$ & $23 \pm 8(3)$ \\
\hline PGE-2 $(100 \mu \mathrm{g})$ & 22 & 09:00 & $40 \pm 12(5)$ & $19 \pm 7(6)$ \\
\hline PGE-2 $(100 \mu \mathrm{g})$ & 22 & $21: 00$ & $41 \pm 16(4)$ & $23 \pm 8(3)$ \\
\hline Conceptus removal $\ddagger$ & 22 & $15: 00$ & $\left.{ }^{* *} 49 \pm 12(8)\right\}$ & $239+57^{(8)}$ \\
\hline Fetus removal $\ddagger$ & 22 & $15: 00$ & $158 \pm 38(8)\}$ & $259 \pm J 1(8)$ \\
\hline hCG (300 i.u.) & 22 & 09:00 & $* 82 \pm 21(6)$ & $17 \pm 10(5)$ \\
\hline hCG (300 i.u.) & 22 & $15: 00$ & $116 \pm 5(5)$ & $91 \pm 22(5)$ \\
\hline Cycloheximide (1 mg) & 22 & $15: 00$ & $* 2 \pm 1(4)$ & $289 \pm 106(4)$ \\
\hline
\end{tabular}

Values are mean \pm s.e.m. for the no. of rats in parentheses.

$\dagger$ Rats were killed $5 \mathrm{~h}$ after each treatment.

$\ddagger 12 \mathrm{~h}$ before death.

Compared with control values, ${ }^{*} P<0.05$; ** $P<0.01$; *** $P<0.001$ (Student's $t$ test).

dependence of ornithine decarboxylase on Day 22 and, in certain cases, on Day 21. Both peak activities were substantially reduced following injection of aminoglutethimide or indomethacin. PGF- $2 \alpha$ significantly $(P<0.01)$ restored the activity on Day 22 inhibited by indomethacin (data not shown). In a separate experiment oestradiol-17 $\beta$ appeared to reverse the inhibition by 
aminoglutethimide but, because of evident lack of synchrony in this particular group of rats, the result achieved only low statistical significance (data not shown). The peak ornithine decarboxylase activity on Day 22 could not be enhanced significantly by prior administration of PGF-2 $\alpha$, PGE- 2 or oestradiol-17 $\beta$. On the other hand oestradiol $17 \beta$ did increase the activity at the off-peak times of 17:00 h on Day 21 and 10:00 h on Day 22, but not at 21:00 h on Day 22 . Similarly, PGF-2 $\alpha$ enhanced the activity at 09:00 h but not at 21:00 h on Day 22, whereas PGE-2 was ineffective at these times. Thus the corpora lutea appeared to be refractory to hormonal stimuli in the evening of Day 22.

The peak activity of ornithine decarboxylase on Day 22 was greatly reduced by prior removal of the entire conceptus, but not significantly by removal of the fetuses only. Administration of hCG caused an increase in activity at 09:00 h, but none at 15:00 h on the same day. Injection of a few rats with cycloheximide confirmed that the enzyme activity is abolished by the interruption of protein synthesis, consistent with a rapid turnover of enzyme protein.

\section{Discussion}

The observations of luteal ornithine decarboxylase recorded here are of two sorts-values measured in pregnant or pseudopregnant rats, and those measured after a given treatment. In selecting the treatments to be applied, the doses and times of administration have been chosen on the basis of our own and others' experience with these agents. It was beyond the scope of the present investigation fully to explore dose-response and time-response relationships with a view to achieving optimal effects, and this must be taken into account in the interpretation of results.

The elevation of luteal ornithine decarboxylase activity between Days 12 and 20 of pregnancy, its premature induction by hCG, its great reduction when the placentae are removed and partial restoration when hCG is also given, and finally its complete absence in 13-17-day-pseudopregnant rats, lend support to the proposed existence of a rat chorionic gonadotrophin of hCG-like properties. The withdrawal of such a hormone after Day 21 of pregnancy would also afford an explanation for the decline in luteal progesterone secretion and in ornithine decarboxylase activity, and for the induction of luteal $20 a$-hydroxysteroid dehydrogenase. It appears that oestrogen is essential for the maintenance of luteal ornithine decarboxylase activity on Day 18, but that prostaglandin is not. This may be related to the oestrogen requirement for the suppression of $20 a$-hydroxysteroid dehydrogenase activity (Hickman-Smith \& Kuhn, 1976).

The two brief peaks of ornithine decarboxylase activity on Days 21 and 22 are best ascribed to two pulsed stimuli, that we provisionally assume to be similar. The stimuli are not obviously diurnal, since they occurred at different times of day and since no such activity peaks occurred on the preceding Day 20. Both peak activities appear to be dependent upon the availability of oestrogen and prostaglandin and, where tested, also upon the presence of the placentae. It is therefore an interesting possibility that a pulsatile release of PGF- $2 \alpha$ from the placenta might constitute the natural stimulus, since a participation of this hormone in luteolysis, including the normal induction of $20 \alpha$-hydroxysteroid dehydrogenase, is also strongly indicated (Strauss \& Stambaugh, 1974).

It is not part of this investigation to explore the consequences of ornithine decarboxylase induction in the corpora lutea, but its induction in tissues generally is believed to accompany cellular differentiation or proliferation (Abraham \& Pihl, 1981). The present study shows, however, that ornithine decarboxylase provides a useful tool for monitoring, and subsequently identifying, hormonal influences on the ovary. Our results, together with previous observations referred to in the 'Introduction', suggest a working hypothesis in which the withdrawal of a placental gonadotrophin and the appearance of placental PGF-2 $\alpha$ together constitute the luteolytic signal in the late-pregnant rat. Oestrogen seems more likely to act in a supporting capacity to maintain luteal viability. 
We thank Mrs Dorothy Clark for expert animal husbandry. L.E.B. is a recipient of a Fellowship from Programme BID-C.O.N.I.C.E.T. Republica Argentina.

\section{References}

Abraham, A.K. \& Pihl, A. (1981) Role of polyamines in macromolecular synthesis. Trends Biochem. Sci. 6, $106-107$.

Bambra, C.S. \& Gombe, S. (1978) The role of placental gonadotrophins (PMSG and hCG) in pregnancy in the rat. J. Reprod. Fert. 53, 109-115.

Blank, M.S., Dufau, M.L. \& Friesen, H.G. (1979) Demonstration of a potent, gonadotropin-like biological activity in the serum of rats during midpregnancy. Life Sci. 25, 1023-1028.

Bussmann, L.E. \& Deis, R.P. (1979) Studies concerning the hormonal induction of lactogenesis by prostaglandin $F_{2 \alpha}$ in pregnant rats. J. Steroid Biochem. 11, 1485-1489.

Conti, M., Harwood, J.P., Dufau, M.L. \& Catt, K.J. (1977) Effect of gonadotropin-induced receptor regulation on biological responses of isolated rat luteal cells. J. biol. Chem. 252, 8869-8874.

Fuchs, A.R. \& Mok, E. (1974) Histological study of the effects of prostaglandins $F_{2 a}$ and $E_{2}$ on the corpus luteum of pregnant rats. Biol. Reprod. 10, 24-38.

Harney, P.J., Sneddon, J.M. \& Williams, K.I. (1974) The infuence of ovarian hormones upon the motility and prostaglandin production of the pregnant rat uterus in vitro. J. Endocr. 60, 343-351.

Hickman-Smith, D. \& Kuhn, N.J. (1976) A proposed sequence of hormones controlling the induction of luteal $20 \alpha$-hydroxysteroid dehydrogenase and progesterone withdrawal in the late-pregnant rat. Biochem. J. 160, 663-670.

Hickman-Smith, D. \& Kuhn, N.J. (1980) Diurnal variation in the inducibility of luteal $20 \alpha$-hydroxysteroid dehydrogenase in pregnant rats. $J$. Endocr. $85,145-149$.

Kobayashi, Y., Kupelian, J. \& Maudsley, D.V. (1971) Ornithine decarboxylase stimulation in rat ovary by luteinising hormone. Science, N.Y. 172, 379-380.

Kuhn, N.J. (1969) Progesterone withdrawal as the lactogenic trigger in the rat. J. Endocr. 44, 39-54.

Kuhn, N.J. \& Briley, M.S. (1970) The roles of pregn-5-ene-3 $\beta, 20 \alpha$-diol and $20 \alpha$-hydroxysteroid dehydrogenase in the control of progesterone synthesis preceding parturition and lactogenesis in the rat. Biochem. J. 117, 193-201.

Labhsetwar, A.P. \& Watson, D.J. (1974) Temporal relationship between secretory patterns of gonadotropins, estrogens, progestins and prostaglandin- $F$ in periparturient rats. Biol. Reprod. 10, 103-110.
Lamprecht, S.A., Zor, U., Tsafriri, A. \& Lindner, H.R. (1973) Action of prostaglandin $E_{2}$ and luteinising hormone on ovarian adenyl cyclase, protein kinase and ornithine decarboxylase activity during postnatal development and maturity in the rat. $J$. Endocr. 57, 217-233.

Lincoln, D.W. \& Porter, D.G. (1976) Timing of the photoperiod and the hour of birth in rats. Nature, Lond. 260, 780-781.

Lincoln, D.W. \& Porter, D.G. (1979) Photoperiodic dissection of endocrine events at parturition. Anim. Reprod. Sci. 2, 97-115.

Moudgal, N.R., Behrman, H.R. \& Greep, R.O. (1972) Effect of luteinising hormone antiserum on progesterone and 20a-dihydroprogesterone secretion in the pregnant rat. J. Endocr. 52, 413-418.

Mukku, V. \& Moudgal, N.R. (1976) Relative sensitivity of the corpus luteum of different days of pregnancy to LH-deprivation in the rat and hamster. Molec, cell. Endocr. 6, 71-80.

Nureddin, A. (1977) Ovarian ornithine decarboxylase induction: a specific and rapid in vivo bioassay of LH. Biochem. Med. 17, 67-79.

Rodway, R.G. \& Kuhn, N.J. (1975) Hormonal control of luteal 20a-hydroxysteroid dehydrogenase and $\Delta^{5}-3 \beta$-hydroxysteroid dehydrogenase during luteolysis in the pregnant rat. Biochem. J. 152, 433-443.

Russell, D.H. \& Snyder, S.H. (1968) Amine synthesis in rapidly growing tissues: ornithine decarboxylase activity in regenerating rat liver, chick embryo and various tumors. Proc. natn. Acad. Sci. U.S.A. 60, 1420-1427.

Sheth, A.R. \& Moodbidri, S.B. (1977) Significance of polyamines in reproduction. In Regulatory Mechanisms Affecting Gonadal Hormone Action, pp. 51-74. Eds J. A. Thomas \& R. L. Singhal. HM \& M Medical \& Scientific Publishers, Aylesbury.

Strauss, J.F. \& Stambaugh, R.L. (1974) Induction of $20 a$-hydroxysteroid dehydrogenase in rat corpora lutea of pregnancy by prostaglandin $\mathrm{F}_{2 \alpha^{*}}$. Prostaglandins 5, 73-84.

Tabor, C.W. \& Tabor, H. (1976) 1,4-Diaminobutane (putrescine), spermidine, and spermine. Ann. Rev. Biochem. 45, 285-306.

Wiest, W.G., Kidwell, W. \& Balogh, K. (1968) Progesterone catabolism in the rat ovary: a regulatory mechanism for progestational potency during pregnancy. Endocrinology 82, 844-859. 